\title{
THE EFFECT OF JOB ROTATION ON CAREER MANAGEMENT
}

\author{
MD LAZIM MOHD ZIN \\ School of Business Management \\ Universiti Utara Malaysia
}

\begin{abstract}
Job rotation is a type of on-the-job training where an employee is encouraged to gain a range of information, skills and competencies in the workplace. The purpose of this study is to examine the influence of job rotation on career management. Toward this objective, a survey was carried out amongst 76 assistant registrars in one public university in Malaysia. Factor analysis has revealed that there are three distinct dimensions of job rotation, namely, business knowledge, technical knowledge and administrative knowledge, as well as a single dimension of career management. Multiple regression results shows that only two dimensions of job rotation have significantly influence on career management, with the exception of business knowledge. This finding has also indicated that job rotation practice affects the career management through the enhancement and enrichment of employees' knowledge and skills, which in turn will influence their career progression in the workplace.
\end{abstract}

Keywords: Career Management; job rotation; knowledge and skills; career progression; promotion.

\section{Introduction}

Job rotation refers to the systematic movement of employees from job to job or any change in assignment, job content or department within the organization (Arya \& Mittendorf, 2014; Baro, 2012; Kaymaz, 2010; Lazim, Faridahwati \& Subramaniam, 2013; Syukri, Arsiah \& Dousin, 2013). It implies a systematic change of employee by transferring employee between various area of responsibility on the premise to enhance employee experience in the job (Campion \& Cheraskin, 1996). According to Kaymaz (2010), job rotation has important implications for firm learning, which gives information about many different job-employee matches. He addressed a number of reasons as to why job rotation policy needs to be implemented. Firstly, when there is uncertainty about the productivity and profitability of different persons at different jobs. Second, where firms adopting new technologies, job rotation could be used as a tool to ensure employees acquire the skills that new technologies required. Lastly, job rotation is used to learn more about different employees activities in the organization. On the other hand, literature on functional flexibility suggests that job rotation is a central element within the frame of discussion on employee flexibility (Hodgson, Al-Shehhi \& Marzouqi, 2014; Friedrich, Kabst, Weber, \& Rodehuth, 1998). According to Friedrich et al., (2004) functional flexibility is often associated with different models of work system such as job enlargement, job rotation and semi-autonomous work groups. Their finding suggests that by taking over new tasks and by exercising functions independently and responsibly, the employee knowledge and 
abilities are enhanced and an impression of the diversity of the company's individual tasks is conveyed to them.

In general, the purpose of the job rotation policy for this particular university is to enable staff members to develop knowledge, new skills and a broader understanding of operations and to more effectively use their current level of competencies, knowledge and skills. The general guideline for job rotation practice is it involves the temporary assignment of an employee in a particular position or department for a specified period of time (at least 2 years) to perform the specific duties of another position. This is not a voluntary assignment where the employee treats the assigned duties as part of their regular responsibilities, but it is a compulsory rotation decision made by university management. In addition, an employee who participates in the job rotation practice, normally remain in the same job status, classification and shall retain all rights, benefits and privileges of the present position. However, there are slight changes on the job description and tasks to be performed, this depends on the core business and job nature at the new department.

In this study, the main idea was to examine to what extent the implementation of job rotation will effect the career management, particularly in a public university setting. Job rotation practice in an organization has attracted many scholars to examine its roles and contributions in career development among employees in organizations (Campion, Cheraskin \& Stevens, 1994; Campion \& Cheraskin, 1996; Lazim et al., 2013). Despite the organizational interest in embarking employees' competencies, several issues on career development programmes arose because of the poor match between job rotation outcomes and employees' career goals. Although there was increased research on job rotation and its influence on career management, there is minimal empirical research about the implementation of job rotation as a career development tool in a public university in
Malaysia. Hence a gap exist in the literature pertaining to job rotation in the public university context, thus, this study fills the gap by examining the relationship between job rotation and career development among assistant registrar in this public university in Malaysia.

\section{Theoretical Background and Hypotheses Development}

\section{Career Management}

The concept of career management can be defined in various ways. In general, career management as career exploration, development of career goals and career strategy implementation (Azman, Nurrul \& Rizal, 2014; Christopher, 1994; Hall, 1986). According to Christopher (1994), individual career management refers to the employees efforts to advance their own career goals. The concept of career management is further described by Hall (1986) and Christopher (1994), which presented the roles of employers and employees in career management activities. For instance, employees are responsible to provide accurate information to management about employee skills, work experience and career aspirations. Likewise, managers are responsible to identify career development opportunities for employees and to ensure that this helps employees achieve their career goals (Christopher, 1994). Thus, in this employment relationship, career management can be broadly defined as a lifelong process of work-related activities that includes both objective and subjective process for achieving specific employees and organization goals (Mignonac, 2008). This career management practice is crucial for developing human capital development and for providing career information to employees, helping employees identify advancement opportunities and promoting career enhancement in the workplace. In short, career management activities can help employees discover their vocational interests and strengths, whilst, employers can make it as a way to attract the best employees and retain them over time. 


\section{The Relationship between Job Rotation and Career Management}

Several researchers addressed the crucial relationship between job rotation and career management (McCall, Lombardo, \& Morrison, 1988; Noe \& Ford, 1992; Tannenbaum., 1997; Wright \& Belcourt, 1994) studied various outcomes of career management. According to Noe and Ford (1992), career development is one of the intended outcomes of job rotation practice. In this aspect, job rotation is properly designed to promote the employees career development at some level through actively participating in training and career counseling. A study by Wright and Belcourt (1994) also concluded that job rotation is a primary vehicle for employee development in the organization. They have suggested that learning from experience or learning by performing the rote in the business simulation and job rotation can enrich employees' development opportunities. This argument is made based on the premise that learning and experiencing many functions within the organization can provide them with multiple areas of expertise.

In a report on a specific case of job rotation for employees' continuous learning, Tannenbaum (1997) has demonstrated that individuals who participate in a relevant learning experience through job rotation practice would help them to develop new competencies that could be applied on the job. As a result, their new skills and knowledge are recognized and rewarded, which in turn, can instil greater motivation in them and will encourage them to seek another learning experiences. Meanwhile, Gabarro (1987) further found that executives' past work experience was critical in determining their successful adjustment after a transition. Similarly, McCall et al. (1988) found that the events that that executives experienced in previous jobs had an influence on what they learned with regard to management and business strategy.

In view of employee responsibility for their career enhancement, Uzoamaka, James and Susan (2000) suggested that they need to be aware of their environment as a preparation for any uncertainty in career development in the future. They proposed that in the new career development contract, individuals are required to be responsible ultimately for their careers, but organizations should become partners and provide resource to enable employees to excel themselves in the career world. This situation has brought essential effects on individual career that the effective management of an employee's career within the organization can make an essential contribution to an organization in achieving competitive advantage from within (Coolahan, 1996). Thus, for both individuals and employer, they must embrace continuous learning in an effort to create a better employeeorganization fit, a better employee-job fit and increase employee loyalty (Kirk, Downey, Duckett \& Woody, 2000). Furthermore, providing meaningful developmental experiences are necessary if the company is to have a pool of candidates for future management positions. On the job experiences is required and job rotation should be practiced in order to provide employees a better way for gaining expertise, skills and knowledge in the proper manner.

Some researchers have examined through empirical research that knowledge and skills are frequently used as a basis for employee development (Tesluk \& Jacobs, 1998; Uzoamaka et al., 2000). For example, Tesluk and Jacobs (1998) addressed knowledge and skills development in the model of experience as the direct outcomes of work experience. The development of work experience can be gained through training and development in the workplace. Pertaining to this model, the number of times a task has been performed (i.e., amount) can enhance proficiency by honing skills through practices. Likewise, Brown and Reich (1997) stressed that skills are developed partly through job experiences, of which placing On-the-Job Training (OJT) as the best training technique to expand an employee's skill and abilities. They studied skill development of the Japanese training system, which was really impressive. It comprises of the effectiveness of OJT, including the assignment of difficult tasks, promotion to higher positions and annual job rotation. 
The general results above demonstrated that job rotation practice is strongly believed to enhance employees competencies, as reflecting on the promotional opportunity, is crucial in providing bright career development in the future. Based on this underlying assumption, job rotation is believed to have significant relation with career management. Therefore, in this study, the research framework is developed based on the literature above, and is as shown in Figure 1 below.

Figure 1. Theoretical Framework

\section{Research Hypotheses}

The relationship between job rotation and career management can be explained empirically by looking at the previous research done by prominent scholars in various areas such as training and development, organization learning, employee learning and job flexibility (Burke \& Steensma, 1998; Campion et al., 1994; Campion \& Cheraskin, 1996; Friedrich et al., 1998; Lazim et al., 2013). In general, Campion and Cheraskin (1996) stated that job rotation should be used as a way to achieve many different human resources objectives such as to enhance the value of work experience, to prevent job boredom and to enhance their career development. Likewise, Lazim et al., (2013) managed to examine the influence of job rotation on individual outcomes, specifically, to link job rotation to career development among production workers in Japanese companies in Malaysia. Eriksson and Ortega (2001) in their study found that job rotation is an effective way to develop employee ability and this is applicable to those who need to be trained in the workplace. Furthermore, Azman et al., (2014) supported that rotation is an effective tool for acquiring skills that an employee needs to master the new technologies. This finding shows that job rotation produced a lot of opportunity for employees to learn new knowledge, skills and experiences in the workplace, which indirectly will influence promotion opportunity in the future. This is consistent with the fundamental characteristic of promotion practice in organization which takes into account the level of knowledge and skills of employees as its main concern. For example, Marian et al. (1995) reported that promotions for both men and women were based on combination of proven competences and the potential for development such as experience, track record, skill, work ethic and interpersonal skill. In addition, employee's ability to work in a team, interpersonal skill and the potential for growth were the main reasons for promotion decisions making. According to Coolahan (1996), individual career progression generally takes the view that career advancement is a function of education, ability, job experience and skills. Essentially, an employee's career progression within the organization may be restricted if there is a mismatch between the abilities and attributes of the individual and the requirements of the job. Therefore, the following hypotheses are proposed:

H1 : Perceptions of job rotation (administrative knowledge) has a positive influence on career management. 
H2: Perceptions of job rotation (business knowledge) has a positive influence on career management.

H3 : Perceptions of job rotation (technical knowledge) has a positive influence on career management.

\section{Methodology}

\section{Study Sample and Data Collection Procedure}

A total of 150 questionnaires were mailed to a representative of the public university who agreed to participate in this study. The representative distributed the questionnaires to the assistant registrars. Each participant received one set of questionnaire with a cover letter attached, explaining the purpose of the study and the instructions on how to answer the questionnaire. Participants were also provided with a pre-addressed and postage-paid envelope so that they could post the questionnaire back to the researcher. The respondents were randomly selected within the university. In total, 83 questionnaires were returned (after a three week collection period) to represent the sample of this study, and this amounted to a response rate of 55.33 per cent. However, 7 responses were eliminated due to excessive missing data. Therefore, the reliable sample size for testing the research hypotheses for the present study was 76 which makeup 50.67 per cent of the response rate.

The participant of the study were mainly made up of female (67.5 per cent), married (67 per cent), of Malay origin (53 per cent, and majority have a Bachelor degree as their highest qualification (36.4 per cent). The mean age was 34.45 years, and the mean length of service was 4.35 years.

\section{Measurement}

Career management was operationalized as employees perceptions towards multiple career options in the present and future position in the organization which includes promotional opportunity, and skills improvement. Career management was measure using five items adapted from Ledkin and Juwaheer (2000). All items employed a five-point scale ranging from ' 1 ' "strongly disagree" to ' 5 ' "strongly agree". Examples of items include 'creates a working environment that allows me to advance in my career".

Job rotation was operationalized as employees' perceptions of knowledge and skills gained from job rotation practice. This construct was measured using an instrument containing 13 items, adapted from Campion et al. (1994). All items employed a five-point scale ranging from ' 1 ' "strongly disagree" to ' 5 ' "strongly agree".

The final part of the questionnaire measured age, sex, tenure, marital status and education as demographic information which were determined by asking a single, objectively worded question.

\section{Results}

\section{Factor Analyses}

To address the validity of the measure, a factor analysis with principle component analysis employing an arthogonal varimax rotation was carried out on five constructs. The criteria used by Igbaria, Juhani and Maragahh (1995) was adapted to identify and interpret factors were: each item should load 0.50 or greater on one factor and 0.35 or lower on the other factor.

Firstly, a factor analysis was carried out on career management measures. The result confirmed the single factor solution with eigenvalues greater than 1.0 and the total variance explained was $67.43 \%$ of the total variance. The Kaiser-MeyerOlkin (KMO) measure of sampling adequacy was 0.76 indicating sufficient intercorrelations while the Bartlett's Test of Sphericity was significant (Chi square $=642.31, \mathrm{p}<0.01$ ). Table 1 shows the results of the factor analysis for career management. 
Table 1

Factor Analysis on Career Management

\begin{tabular}{llc}
\hline Career Management Items & Component 1 \\
\hline 1. I prefer working environment that allows me to advance in my career. & .788 \\
2. I believe skills and knowledge gained help me to improve my capabilities. & .703 \\
3. I believe promotion should be made on the basis of work experience. & .642 \\
4. I believe self-confident is valuable in my career enhancement. & .678 \\
5. I believe continues training is important for my future career. & .630. \\
\hline Eigenvalue & 3.42 \\
Percentage of variance explained (\%) & 67.43 \\
Kaiser-Meyer-Olkin & .76 \\
Bartlett's Test of Sphericity Approx. Chi Square & 642.31 \\
df & 16 \\
Significance Level & .000 \\
\hline
\end{tabular}

The second factor analysis with varimax rotation was conducted to validate the dimensionality of job rotation. A three factor solution that explains $64.24 \%$ variance in job rotation was found. KMO measure of sampling adequacy was 0.617 indicating sufficient intercorrelations while the
Bartlett's Test of Sphericity was significant (Chi square $=643.386 \mathrm{p}<0.01$ ). The three factors found are administrative knowledge, technical knowledge and business knowledge. Table 2 presents the result.

\section{Table 2}

\section{Factor Analysis on Job Rotation}

\begin{tabular}{|c|c|c|c|}
\hline \multirow[t]{2}{*}{ Job Rotation Items } & \multicolumn{3}{|c|}{ Components } \\
\hline & 1 & 2 & 3 \\
\hline \multicolumn{4}{|l|}{ Factor 1: Administrative knowledge } \\
\hline 1. Improve planning and organising skills. & .773 & -.268 & .046 \\
\hline 2. Improve interpersonal skills. & .657 & .234 & .174 \\
\hline 3. Improve leadership skills. & .646 & .338 & .346 \\
\hline 4. Increase self-improvement. & .560 &.-146 & .166 \\
\hline 5. Improve cognitive skills. & .712 & .070 & .143 \\
\hline
\end{tabular}




\begin{tabular}{|c|c|c|c|}
\hline \multirow[t]{2}{*}{ Job Rotation Items } & \multicolumn{3}{|c|}{ Components } \\
\hline & 1 & 2 & 3 \\
\hline \multicolumn{4}{|l|}{ Factor 2: Technical knowledge } \\
\hline $\begin{array}{l}\text { 1. Enhance knowledge of organization policies, } \\
\text { procedures and practices. }\end{array}$ & .032 & .713 & .039 \\
\hline 2. Improve production knowledge. & .255 & .649 & -.160 \\
\hline 3. Improve knowledge of business contact and network. & .404 & .597 & -.232 \\
\hline 4. Improve communication network. & .021 & .764 & .073 \\
\hline \multicolumn{4}{|l|}{ Factor 3: Business knowledge } \\
\hline 1. Improve knowledge of general/current issues. & .073 & -.051 & 697 \\
\hline 2. Improve knowledge of department's role. & .211 & .251 & .659 \\
\hline 3. Improve knowledge of external environment of & .065 & .070 & .753 \\
\hline business. & .225 & .175 & .674 \\
\hline \multicolumn{4}{|l|}{ 4. Understand organization goals. } \\
\hline & -.214 & .186 & .454 \\
\hline Eigenvalue & 1.24 & 1.22 & 1.02 \\
\hline Percentage of variance explained $(\%)=64.24$ & 10.426 & 8.655 & 8.121 \\
\hline \multicolumn{4}{|l|}{ Kaiser-Meyer-Olkin $=.617$} \\
\hline \multicolumn{4}{|l|}{ Bartlett's Test of Sphericity Approx. Chi Square = } \\
\hline \multicolumn{4}{|l|}{633.386} \\
\hline $\mathrm{df}=18$ & & & \\
\hline Significance Level $=.000$ & & & \\
\hline
\end{tabular}

\section{Means, Internal Reliability and Correlations}

Table 3 presents the means, standard deviation, scale reliabilities and Pearson correlations of the study. Coefficient alpha for the adapted scales were: administrative knowledge = .720 , technical knowledge $=.830$, business knowledge $=.741$ and career management $=$

Table 3

Descriptive Statistic, Scale Reliabilities and Correlations Variables

\begin{tabular}{lcccccc}
\hline Variables & Mean & SD & AK & TK & BK & CM \\
\hline $\begin{array}{l}\text { Administrative } \\
\text { knolwedge (AK) }\end{array}$ & 3.57 & 1.99 & $.422^{*}(.720)$ & & & \\
$\begin{array}{l}\text { Technical knowledge } \\
\text { (TK) }\end{array}$ & 3.87 & 2.41 & $.318^{* *}$ & $.512^{* *}(.830)$ & & \\
\hline
\end{tabular}

(Continued)
.634. In terms of correlations amongst variables, as shown in the table, all three job rotation measures, administrative knowledge $(r=321$, $\mathrm{p}<01)$, technical knowledge $(\mathrm{r}=.531, \mathrm{p}<.05)$, and business knowledge $(\mathrm{r}=.374, \mathrm{p}<.01)$, were found significantly positively correlated with career development. 


\begin{tabular}{lcccccc}
\hline Variables & Mean & SD & AK & TK & BK & CM \\
\hline $\begin{array}{l}\text { Business knowledge } \\
\text { (BK) }\end{array}$ & 4.45 & 2.27 & $.201^{* *}$ & $.376^{* *}(.741)$ & & \\
Career management & 4.21 & 2.39 & $.321^{*}$ & $.531^{* *}$ & $.374 *(.634)$ & \\
$(\mathrm{CM})$ & & & & & & \\
\hline Note $: * p<.05, * * p<.01$ & & & & &
\end{tabular}

\section{Multiple Regressions}

Multiple regression was conducted for testing $\mathrm{H} 1, \mathrm{H} 2$, and $\mathrm{H} 3$. Multiple regression analysis is used to predict the proportion of the variance in dependent variable is explained by the independent variables. It is noted that $45.4 \%$ of the variance in career development had been significantly explained by the administrative knowledge, and technical knowledge. In the model, out of three job rotation measures, two variables were statistically significant on positive relationship with career management, with administrative knowledge recording a higher beta value $(\beta=.435, p<.01)$, and followed by technical knowledge $(\beta=.320, \quad p<.01)$. However, business knowledge is not related to career management. Thus, H1, and H3 were supported. Table 4 presents the results of multiple regression analysis.

Table 4

Multiple Regression Results

Independent Variables

Dependent Variable:

Career Management

Administrative knowledge

$.435 * *$

Technical knowledge

$.320 * *$

Business knowledge

.192

$\mathrm{R}^{2}$

.454

.410

Adj. $R^{2}$

$32.170^{* *}$

Note: $* p<.05, * * p<.01$

\section{Discussion}

The present study seeks to examine the relationship between job rotation and career management amongst assistant registrar. As expected, the results of multiple-regression revealed that job rotation measures were found to be positively related to career management. Specifically, the present study found that administrative and technical knowledge are significant predictors of career management. One of the possible reasons for this relationship is that the role of job rotation practice can enhance employees' level of competencies. In this context, knowledge and skills gained from job rotation has a unique value for career progression and promotion purposes among assistant registrar. For instance, according to Campion et al., (1984), job rotation might be used to provide a change of scene through 
new duties, skill demands or location. This can provide some of the stimulation normally associated with promotion and career planning in the organization.

Another possible justification is the tendency for management to promote employees who have already experienced part of the new job, this indirectly will help employees to participate in the job rotation. In general, most organizations are more likely to promote employees who were strongly associated with previous experience to higher position. The job related experience such as the ability to work in team, strong work ethic and good understanding of organization business may place assistants registrar in strong positions to be selected as suitable candidates for promotion. Consequently, job rotation practices should be used to equip employees with the best possible skills, knowledge and performance for promotion.

Findings from the present study have several implications for both theoretical and practice. From the theoretical perspective, the positive relationship between administrative knowledge, technical knowledge and career management outcomes indicated that there is a tendency among assistant registrar in public university to progress in their career in the organization by actively participating in job rotation. In this context, job rotation system must be developed systematically. Theoretically, the systematic job rotation practice should has clear policies regarding who will be eligible for the programme and, whether employees will be restricted to certain jobs or they will be eligible for all job classifications. In addition, employees and managers involvement in planning, designing and implementing job rotations should practice transparently. This is important to ensure that there is a clear understanding of its goals, objectives and mutual expectations of its final outcomes for employees career development.

Secondly, the findings of the current study indicated that job rotation may be related to the development of an executive career because it increases management experience in many ways. For instance, job rotation is purposely conducted to provide managers with a broad knowledge of different areas of business, to enable them to develop a network of organizational contacts and to increase their problem-solving skills. London and Mone (1988) also explained job rotation in the context of developing managers into generalists. Research by Burke and Steensma (1998) reported that job rotation is widely used as a means of developing intrapersonal heterogeneity in top management team (TMT) members to influence firm performance by improving TMT decision-making process.

In terms of implications for practice, the research finding show that job rotation had significantly correlated with employee perception towards career development opportunity. From this standpoint, human resource executives can draw a clear understanding of the essential influence of job rotation on assistant registrar promotion decisions. Specifically, job rotation provides an incentive to the organization to promote workers from within, especially employees who have acquired the sets of skills and knowledge needed for a higher-level position in the public university. At the same time, job rotation provides information that the organization can use in improving the allocation of jobs among employees. In other words, it may be easier for the management team to determine the most appropriate job for the assistant registrar in future.

Finally, with regard to knowledge and skill acquisition and its influence on career development, human resource executives should be aware of the importance of training activities in the workplace. Nowadays, the impact of new technologies in managing the operations of public university also calls for more emphasis on workplace training programmes. To achieve these, managers are responsible for linking the organization's needs to the employee's career goals, and to assist employees in the career planning process. In addition, they are also responsible for designing career paths and employee development programmes that can help employees reach their goals. 


\section{Limitations and Directions for Future Research}

This study is subjected to two major limitations. First of all, this study was conducted on a relatively small sample ( $\mathrm{n}=76$ assistant registrar) in a public university, so generalisation of results and conclusions can be questioned. The respondents who participated in this study were only from a public university in Malaysia, which raises the issue as to whether their interest to participate in job rotation and their perception towards career development outcomes can be generalised as compared to other groups of employees in private universities or colleges.

Secondly, since this study is descriptive and quantitative in nature, with the sole use of a questionnaire survey to obtain data regarding assistant registrars perception towards job rotation and career development outcomes, and these might not cover the real feeling of the respondents. A combination of questionnaire surveys and a series of interviews are recommended in future, for the gathering of more data and to improve the overall findings of the study.

\section{Conclusion}

The aim of this study was to investigate the relationship between job rotation and career management among assistant registrars. Since job rotation practice is related to career development, management of organization should focus more on improving the implementation of job rotation and to consider the career development in the organization. In other words, job rotation is conducive in improving effectiveness and productivity of employees and organizations. It helps assistant registrars to learn new skills and knowledge and overcome boredom and job dissatisfaction. It is hope that through the examination of these factors, a complete understanding of the best approach to embark in career development among assistant registrars will be achieved.

\section{Acknwoledgments}

Without the dedication and support from these people, the completion of this research would not have been possible. I would like to thank to Universiti Utara Malaysia especially for granting this research, and also to all management staff for all the energy, care, and enthusiasm that they have devoted to this effort. A word of appreciation also goes to all participants, for their involvement in this study.

\section{References}

Arya, A., \& Mittendorf, B. (2014). Using job rotation to extract employee information. Journal of Law, Economics and Organization, 20(2), 400-410.

Azman, I., Nurrul, H.A., \& Rizal, A.B. (2014). Perceived career development support in workplace career programme. Economic Annals, 20(7), 157-175.

Baro, E.E. (2012). Job rotation program evaluation: the Niger Delta University Library. Aslib Proceedings, 64, 388-404.

Brown, C., \& Reich, M. (1997). Developing skills and pay through career ladders. California Management Review, 39(2), 124-144.

Burke, L.A., \& Steensma, H.K. (1998). Toward a model for relating executive career experiences and firm performance. Journal of Managerial Issues, 10(1), 86102.

Campion, M.A., \& Cheraskin, L. (1996). Study clarifies job rotation benefits. Personnel Journal, 75(11), 31-37

Campion, M.A., Cheraskin, L., \& Stevens, M.J. (1994). Career-related antecedents and outcomes of job rotation. Academy of Management Journal, 37, 1518-1542.

Christopher, O. (1994). The effects of organizational and individual career management on career success. International Journal of Manpower, 15(1), 27-37.

Coolahan, M. (1996). Career mobility in organizations: implications for career development - part 1. Journal of 
European Industrial Training, 20(4), 3040.

Eriksson, T., \& Ortega, J. (2001). The adoption of job rotation: testing the theories. Paper presented at Universidal Publica de Navana. Retreived from http://www. econ.unavarra.es/rixtar/papers0102/ jrotationUPNA.pdf

Friedrich, A., Kabst, R., Weber, W \& Rodehuth, M. (1998), Functional flexibility: merely reacting or acting strategically? Employee Relations, 20(5), 504-516.

Gabarro, J.J. (1987). The dynamics of taking charge. In Campion, M..A., Cheraskin, L. , \& Stevens, M.J. (1994) (Eds.), Academy of Management Journal. 37, $1518-1542$

Hall, D.T. (1984). Human resources development and organization effectiveness. Strategic Human Resources Management, 5, 159181.

Hodgson S., Al-Shehhi, M., \& Al-Marzouqi, E. (2014). The effect of job rotation on employees in organizations in the UAE. Middle East Journal of Business. 9(3), 35-46.

Igbaria, M., Juhani, I., \& Maragahh, H. (1995). Why do individuals use computer technology? A Finnish case study. Information and Management. 29, 227 238.

Kaymaz, K. (2010). The effects of job rotation practices on motivatiom. A research on managers in the automotive organizations. Business and Economics Research Journal, 1(3), 69-85.

Kirk, J.J., Downey, B., Duckett, S., \& Woody, C. (2000). Name your career development intervention. Journal of Workplace Planning. 12(5), 205-216.

Lazim, M.Z., Faridahwati, M.S., \& Subramaniam, C. (2013). Investigating the influence of job rotation on career development among production workers in Japanese companies. International Journal of Business and Society, 14(1), 135-148.

Ledkin, A., \& Juwaheer, T.D. (2000). The career paths of hotel general managers in Mauritius. International Journal of
Contemporary Hospitality Management. 12(2), 119-125.

London, M., \& Mone, M. (1988). Career growth and human resource strategies: the role of human resource professional in employee development. New York, Wetsport, Connecticut, London.

Marian, N.R., Patricia, J.O. \& Kathy, E.K. (1995). Promotion decisions as a diversity practices. Journal of Management Development, 14(2), 6-23.

McCall, M.W., Lombardo, M.M., \& Morrison, A.M (1988). The lessons from experience: How successful executives develop on the job. In Campion, M..A., Cheraskin, L., \& .Stevens, M.J. (1994) (Eds.), Academy of Management Journal. 37, 1518-1542.

Mignonac, K. (2008). Individual and contextual antecedents of older managerial employees' willingness to accept intra-organizational job changes. The International Journal of Human Resource Management, 19(4), 582-599.

Noe, R.A., \& Ford, J.K. (1992). Career building: learning from cumulative work experience. Career Development in Organisations, 7, 45-52.

Syukri, S., Arsiah, B. \& Dousin, O. (2013). Job rotation practices, stress and motivation: An empirical study among administrative and diplomatic officers in Sabah, Malaysia. International Journal of Research in Management and Technology, 3(6), 160-176.

Tannenbaum, S.T. (1997). Enhancing continuous leraning: diagnostic findings from multiple companies. Human Resource Management. 36(4), 437-452.

Tesluk, P.E., \& Jacobs, R.R. (1998). Toward an integrated model of work experience. Personnel Psychology, 51(2), 321-355.

Uzoamaka, P.A., James, C.H. \& Susan, M.S. (2000). Knowledge-related skills and effective career management. International Journal of Manpower, 21(7), 566-579.

Wright,P.C., \& Belcourt,M.(1994). Management development: a career management perspective.The International Journal of Career Management, 6(5), 3-10 